\title{
AKUNTABILITAS DAN TRANSPARANSI BERBASIS BAGI HASIL (ANALISIS TERHADAP KARYAWAN TOKO DI KOTA BEUREUNUEN)
}

\author{
Mahlel*, Muhammad Ridwan**, Nasirwan *** \\ 'Universitas Islam Negeri Sumatera Utara (UIN SU) Medan \\ ${ }^{2}$ Universitas Islam Negeri Sumatera Utara (UIN SU) Medan \\ 3Universitas Islam Negeri Sumatera Utara (UIN SU) Medan
}

\begin{abstract}
Research on Accountability and Transparency Based on the results of this study aims to determine the implementation of Accountability and Transparency Based Revenue in Beureunuen City Store. Some Stores in Beureunuen City implement a profit-sharing system with employees. The study was conducted from March 2016 to February 2017.

This research uses qualitative approach. For Collection - to get information about employeesvalidation techniques done by digging information from some informants directly related to the Business. In addition, researchers also conducted direct observation at the location of the study to verify the data whether the data obtained from the informant in line with the reality of the field or not. The result of the research analysis shows that the application of Accountability and Transparency Based on Profit is good. However, there is a weakness in terms of the absence of annual balance sheet. For that researchers offer Balance Sheet report.
\end{abstract}

The implementation of Profit-Based Accountability and Transparency is already well categorized in terms of responsibility to the trustee, providing information to employees and granting the employee rights in accordance with the earnings of the company's profit within one year of Hijriah.

Keywords: Accountability, Transparency and Profit Sharing

\section{PENDAHULUAN}

Persoalan buruh atau ketenagakerjaan merupakan persoalan yang cukup banyak mendapat perhatian dari berbagai kalangan, baik ekonom, pemerhati hukum, maupun pengambil kebijakan. Buruh dengan segala persoalannya seperti upah yang tidak layak, jaminan kesehatan, sistem kontrak dan persoalan lainnya selalu menjadi bahan kajian yang menarik. Di samping itu, Indonesia dengan dua ratus juta lebih jumlah penduduk dimana lebih dari 85 persen penduduk beragama Islam. Dari 85 persen penduduk muslim tersebut, lebih dari 50 persen adalah buruh yang terdiri dari buruh pabrik, buruh lepas, buruh tani, buruh pasar, buruh nelayan, dan lain-lain. Sehingga ketika membicarakan hak buruh secara langsung ataupun tidak kita sedang membic- 
arakan hak-hak kaum muslimin di Indonesia. (Isnaini, 2015:71)

Islam sebagai agama Rahmatal lil 'alamin sangat memperhatikan buruh. Islam datang pada suatu zaman yang penuh dengan kezaliman, penindasan, ketidakadilan dan ketimpangan ekonomi sehingga masyarakat digolongkan ke dalam kelompok-kelompok kecil berbasis suku dan kabilah. Struktur yang seperti ini memunculkan stratifikasi sosial yang sangat kuat. Muncul satu keluarga yang memiliki status sosial sangat tinggi yang memperkerjakan masyarakat dengan status sosial yang lebih rendah. Stratifikasi sosial yang demikian pada akhirnya menjadikan kehormatan seseorang ditentukan oleh asal-usul keluarga dan menciptakan perbudakan.(Isnaini, 2015 :71)

Kedekatan sejarah Islam dengan buruh juga dapat dilihat dari perjalanan Nabi Muhammad Saw, sebelum diangkat sebagai rasul. Sejak kecil hingga menginjak dewasa, Nabi adalah orang yang dipercaya oleh penduduk Mekkah untuk menggembalakan kambing mereka. Menginjak dewasa, Nabi pun akrab dengan perkerjaan buruh, dengan profesinya sebagai pembantu saudagar Khadijah, untuk memasarkan dagangannya di luar daerah.

Al-ajru jamaknya al-ujur, yang dibahas dalam arti upah di Dunia. Beberapa ayat yang berkenaan dengan al-ajru dalam konteks duniawi akan dikaji dan dibahas adalah surah Al-qashas: 26 yang menjelaskan tentang Musa yang hendak diangkat sebagai perkerja pada keluarga seorang yang saleh yang memiliki dua anak, semuanya wanita. Sebelumnya, Musa telah membantu kedua wanita tersebut saat mengambil air untuk minum ternak mereka.

M. Quraish Shihab menafsirkan surah Al-qashas: 26 ayat 23-24 dengan mengatakan, salah seorang dari kedua wanita itu yakni datang mengundangnya berkata: wahai ayahku, pekerjakanlah dia agar ia dapat menangani pekerjaan kita selama ini antara lain mengembala ternak, karena sesungguhnya dia adalah orang yang kuat dan terpercaya dan sesungguhnya orang yang paling baik yang engkau pekerjakan untuk tugas apapun adalah orang yang kuat fisik dan mentalnya lagi terpercaya. (M. Quraish Shihab, 2003: 334)

Dalam pandangan syari'at Islam upah merupakan hak dari orang yang telah berkerja (ajir/employee/buruh) dan kewajiban bagi orang yang memperkejakan (musta'jir/employer/majikan). Meskipun terminologi umum yang digunakan untuk berkerja adalah amal tetapi kata yang di pakai untuk menyebut perkerja adalah ajir bukan amil atau ummal. Kata yang disebut terakhir ini tidak lazim untuk menyebur buruh. Termasuklah didalam makna kata amil (ummal) adalah orang yang berkerja untuk dirinya sendiri. Upah sesungguhnya adalah kompensasi atas jasa yang telah diberikan seorang 
Mahlel, Ridwan, Nasirwan: Akuntabilitas dan Transparansi

tenaga kerja. Perampasan terhadap upah adalah suatu perbuatan buruk yang akan mendapat ancaman siksa dari Allah SWT. (Azhari Akmal Tarigan, 2012: 157)

Diantara hal yang penting dalam hubungan antara majikan dan buruh yaitu upah menempatkannya dalam hubungan yang tepat dan memberikan aturan bagi hubungan timbal balik keduanya untuk mewujudkan keadilan antara mereka. Seorang pekerja berhak untuk mendapatkan upah yang adil atas kontribusinya terhadap keluaran, dan berlawanan dengan hukum bagi seotang majikan Muslim untuk mengekploitasi perkerjaannya.

Maka Upah sangat penting dan memberikan dampak yang luas. Jika perkerja tidak menerima upah yang pantas, maka paritas daya belinya akan menurun sehingga memengaruhi bukan hanya kehidupan pekerja melainkan juga kehidupan keluarganya dan seluruh masyarakat. Turunnya paritas daya beli dalam jangka panjang akan merugikan perusahaan dan industri yang menyediakan barang-barang konsumsi. Di samping itu, ketidakadailan kapada pekerja dengan tidak memberikan upah yang layak kepada mereka akan menimbulkan kekacauan dan rasa tidak senang sehingga memicu aksi pemogokan sehingga mengganggu jalanya perusahaan. (Afzalur Rahman, 1995: 361-362)

Untuk menentukan standar upah yang adil dan batasan-batasan yang menunjukan eksploitasi terhadap perkerjaan, Islam mengajarkan bagaimana menetapkan upah yaitu dengan tidak melakukan kezaliman terhadap buruh ataupun dizalimi oleh buruh. Majikan tidak dibenarkan mengeksploitasi buruh dan buruh juga tidak boleh mengeksploitasikan majikan.

Secara teori dapat dikatakan bahwa upah yang adil adalah upah yang sepadan dengan pekerjaan yang dilakukannya. Tentu saja penetapan tersebut dengan mempertimbangkan situasi serta faktor-faktor yang berkaitan dengan nilai perkerjaan dan penetapan upah yang sesuai, tanpa perlakuan zalim baik kepada pekerja maupun majikan. (Isnaini, 2015: 82)

Penerapan sistem bagi hasil bagi karyawan memberikan keadilan juga dapat memacu semangat kerja karyawan. Bagi hasil tidak hanya berlaku untuk lembaga keuangan saja, tetapi bisa juga diterapkan pada usaha-usaha yang mempunyai karyawan.

Profit dalam bahasa Indonesia disebut juga dengan keuntungan atau laba. Profit merupakan salah satu unsur yang penting dalam perdagangan yang didapat melalui proses pemutaran modal dalam kegiatan ekonomi. Islam sangat mendorong pendayaguaan harta melalui berbagai kegiatan ekonomi dan melarang untuk menganggu- 
rkannya (idle) agar tidak habis dimakan zakat. Bahkan, dorongan ini secara khusus di perintahkan Allah kepada orang-orang yang tidak atau belum mampu melakukan bisnis dengan baik.

Ketentuan ukuran besarnya profit atau laba tidak ditemukan dalam AI-Qur'an maupun hadis. Para pedagang boleh menentukan profit pada ukuran berapa pun yang mereka inginkan, misalnya 25 persen, 50 persen 100 persen atau lebih dari modal. Dengan demikian, pedagang boleh mencari laba dengan persentase tertentu selama aktivitas perdagangannya tidak disertai dengan hal-hal yang haram, seperti ghaban fahisy (menjual dengan harga jauh lebih tinggi atau jauh lebih rendah dari harga pasar ), ihtikar (menimbun), ghisy (menipu), gharar (menimbulkan bahaya) dan tadlis ( menyembunyikan cacat barang dagangan). (Isnaini, 2015: 93)

Para karyawan tidak terlalu ingin mengetahui tentang pencatatan pembukuan tentang uang yang di keluarkan oleh para pengelola Toko, akan tetapi mereka hanya fokus pada melaksanakan tugasnya dan melayani konsumen. Karena para karyawan menganganggap untuk mengetahui tentang pencatatan buku itu bukan kapasitas karyawan. sedangkan pencatatan pembukuan tentang yang masuk dan keluar lebih banyak di lakukan oleh para pemilik dan pengelola toko. Oleh karena itu di perlukannya Akuntabilitas dan transparansi oleh pemilik toko kepada para karyawan yang berkerja supaya di berikan bagi hasil yang adil untuk karyawan.

Akuntabilitas merupakan suatu cara pertanggungjawaban manajemen atau penerima amanah kepada pemberi amanah atas pengelolaan sumber-sumber daya yang dipercayakan kepadanya baik secara vertikal maupun secara horizontal. Dalam definisi tradisional, Akuntabilitas adalah istilah umum untuk menjelaskan bahwa organisasi atau perusahaan sudah memenuhi misi yang mereka emban. (Teguh Arifiaya, 2008) Sedangkan Transparansi adalah keterbukaan dalam melaksanakan proses pengambilan keputusan dan keterbukaan dalam mengemukakan informasi materil dan relevan mengenai perusahaan. (UU No.14 Tahun 2008)

Dalam hal bagi hasil kompensasi antara pemodal dengan karyawan sangat diperlukan akuntabilitas dan transparansi untuk mengetahui tentang perolehan laba dalam jangka waktu satu tahun hijriah.

\section{Teori Akuntabilitas dan Transparansi}

\section{Akuntabilitas}

\section{Pengertian Akuntabilitas}

Akuntabilitas merupakan kewajiban untuk memberi pertanggungjawaban atau un- 
Mahlel, Ridwan, Nasirwan: Akuntabilitas dan Transparansi

tuk menjawab dan menerangkan kinerja dan tindakan seseorang/badan hukum/ pimpinan kolektif suatu organisasi kepada pihak yang memiliki hak atau wewenang untuk meminta keterangan atau pertanggungjawaban. (Edi sukarsno, 2002: 131)

Menurut Sony Yuwono, "Akuntabilitas adalah pertanggungjawaban publik yang memiliki makna bahwasanya proses pengganggaran mulai dari perencanaan, penyusunan dan pelaksanaan harus benar-benar dapat dilaporkan dan dipertanggungjawabkan kepada kepada masyarakat.”(Sony Yuwono, 2005: 59) Lebih lanjut Finner dalam Nico menjelaskan "Akuntabilitas sebagai konsep yang berkenaan dengan standars eksternal yang menentukan kebenaran suatu tindakan birokrasi."(Nico Andrianto: 23$)$

Sedangkan menurut Mckinsey dan Howard dalam Akdon menyatakan bahwa, akuntabilitas murupakan suatu keadaan dimana seseorang yang memiliki dan menggunakan kewenangan tertentu yang dapat dikendalikan, dan pada kenyataannya memang terbatasi oleh ruang lingkup penggunaan kekuasaan oleh instrumen pengendalian eksternal, termasuk sistem nilai internal yang berlaku dalam institusi yang bersangkutan. (Akdon, 2006: 208)

Akuntabilitas adalah pertanggungjawaban dari seseorang atau sekelompok orang yang diberi amanah untuk menjalankan tugas tertentu kepada pihak pemberi amanat baik secara vertikal maupun secara horizontal. Lebih dari itu, akuntabilitas menyangkut pengelolaan keuangan dan kualitas output dan akuntabilitas terkait erat dengan instrumen untuk kegiatan kontrol terutama dalam hal pencapain hasil pada pelayanan publik dan menyampaikan transparan kepada masyaarakat. (Mardiasmo, 2009: 20)

Akuntabilitas adalah membuat setiap laporan kegiatan untuk bisa di pertanggungjawabkan kepada para pemberi amanah.

\section{Akuntabilitas Dalam Perspektif Islam}

Akuntabilitas dalam perspektif Islam tidak hanya ditujukan kepada masyarakat (stakeholders) dalam tataran horizontal melainkan juga pertanggungjawaban vertikal yaitu kepada Allah SWT. ${ }^{1}$ Islam Memiliki pandangan bahwa Akuntabilitas merupakan pertanggungjawaban seseorang manusia sebagai khalifah di bumi kepada sang pencipta yaitu Allah Swt karena apapun yang telah dititipkan kepada manusia merupakan amanah dan setiap manusia harus mempertanggangjawabkan apa yang telah dikerjakan atau diperbuat.

Dari segi akuntansi, akuntabilitas adalah upaya atau aktivitas untuk menghasilkan pengungkapan yang benar melalui proses-proses akuntansi. Pertanggung- 
jawaban pengungkapan tersebut ditujukan kepada Allah dan kepada manusia (stakeholder). Pengungkapan tanggungjawab kepada manusia dapat melalui laporan pertanggungjawaban baik berupa laporan keuangan maupun laporan pelaksanaan kegiatan lainnya. Akuntabilitas juga terkait dengan peran sosial dimana muhtasib (akuntan) yakin bahwa hukum syariah telah dilaksanakan dan kesejahteraan umat menjadi tujuan utama dari aktivitas perusahaan dan tujuan tersebut telah tercapai. Selajutnya yang menjadi indikator pelaksanaa Akuntabilitas dalam perspektif Islam adalah:

a. Segala aktivitas harus memperhatikan dan mengutamakan kesejahteraan ummat sebagai perwujudan amanah yang diberikan Allah kepada manusia sebagai khalifah.

b. Aktivitas organisasi dilaksanakan dengan adil.

c. Aktivitas organisasi tidak merusak lingkungan sekitar.

\section{Bentuk-Bentuk Akuntabilitas}

Akuntabilitas dibedakan menjadi beberapa tipe, diantaranya menurut Rosjidi jenis akuntabilitas dikategorikan menjadi dua tipe yaitu: (Rosjidi, 2001: 145)

1. Akuntabilitas Internal

Berlaku bagi setiap tingkatan organisasi internal penyelenggara pemerintah negara termasuk pemerintah dimana setiap pejabat atau pengurus publik baik individu maupun kelompok secara hierarki berkewajiban untuk mempertanggungjawabkan kepada atasannya langsung mengenai perkembangan kinerja kegiatannya secara periodik maupun sewaktu-waktu bila dipandang perlu. Keharusan dari akuntabilitas internal pemerintah tersebut telah diamanatkan dari Instruksi Presiden Nomor 7 Tahun 1999 tentang Akuntabilitas Instansi Pemerintah (AKIP).

2. Akuntabilitas Eksternal

Melekat pada setiap lembaga negara sebagai suatu organisasi untuk mempertanggungjawabkan semua amanat yang telah diterima dan dilaksanakan ataupun perkembangannya untuk dikomunikasikan kepada pihak eksternal lingkungannya.

Terdapat lima dimensi akuntabilitas yang harus dipenuhi oleh organisasi sektor publik , yaitu: (Syahruddin Rasul, 2002: 11) 
a. Akuntabilitas hukum dan kejujuran (accuntability for probity and legality).

Akuntabilitas hukum terkait dengan dilakukannya kepatuhan terhadap hukum dan peraturan lain yang disyaratkan dalam organisasi, sedangkan akuntabilitas kejujuran terkait dengan penghindaran penyalahgunaan jabatan, korupsi dan kolusi. Akuntabilitas hukum menjamin ditegakkannya supremasi hukum, sedangkan akuntabilitas kejujuran menjamin adanya praktik organisasi yang sehat.

b. Akuntabilitas manajerial

Akuntabilitas manajerial yang dapat juga diartikan sebagai akuntabilitas kinerja (performance accountability) adalah pertanggungjawaban untuk melakukan pengelolaan organisasi secara efektif dan efisien.

c. Akuntabilitas program

Akuntabilitas program juga berarti bahwa programprogram organisasi hendaknya merupakan program yang bermutu dan mendukung strategi dalam pencapaian visi, misi dan tujuan organisasi. Lembaga publik harus mempertanggungjawabkan program yang telah dibuat sampai pada pelaksanaan program.

d. Akuntabilitas kebijakan

Lembaga - lembaga publik hendaknya dapat mempertanggung jawabkan kebijakan yang telah ditetapkan dengan mempertimbangkan dampak dimasa depan. Dalam membuat kebijakan harus dipertimbangkan apa tujuan kebijakan tersebut, mengapa kebijakan itu dilakukan.

e. Akuntabilitas finansial

Akuntabilitas ini merupakan pertanggungjawaban lembaga lembaga publik untuk menggunakan dana publik (public money) secara ekonomis, efisien dan efektif, tidak ada pemborosan dan kebocoran dana, serta korupsi. Akuntabilitas financial ini sangat penting karena menjadi sorotan utama masyarakat. Akuntabilitas ini mengharuskan lembaga-lembaga publikuntuk membuat laporan keuangan untuk menggambarkan kinerja financial organisasi kepada pihak luar.

\section{Tujuan Akuntabilitas}

Tujuan utama akuntabilitas adalah mendorong, terciptanya tanggung jawab untuk meningkatkan kinerja. Menurut Herbert, Killough dan Stretss dalam Waluyo, manajemen suatu organisasi harus "Accountable" untuk: 
1. Menentukan tujuan yang tepat.

2. Mengembangkan standar yangdiperlukan untuk pencapaian tujuan yang ditetapkan.

3. Secara efektif mempromosikan penerapan pemakaian standar.

4. Mengembangkan standar organisasi dan operasi secara ekonomis dan efisien. (Waluyo, 2007: 197)

Dari adanya uraian di atas, maka dapat disimpulkan bahwa tujuan akuntabilitas menciptakan kepercayaan stakeholder dalam pengelolaan keuangan, menetapkan tujuan dan sarana yang tepat dan menggunakan standar dalam proses dan tujuan kegiatan.

\section{Transparans}

\section{Pengertian Transparansi}

prinsip-prinsip yang yang mendasari pengelolaan keuangan adalah transparasi, akuntabilitas dan value for money.(Mardiasmo, 2001:105) Sama halnya dengan prinsip pengelolalan keuangan, perusahaan juga harus menjalankan pengelolaan keuangan dengan memakai prinsip transparansi, akuntabilitas efektivitas dan efesiensi.

Transparansi sendiri memiliki arti keterbukaan dalam proses perencanaan, penyususnan, pelaksanaan anggaran. (Manajemen Keuangan Daerah, h.105) Lebih lanjut Edah Jubaedah menyatakan bahwa, "Transparansi atau keterbukaan adalah prinsip untuk membuka diri terhadap hak masyarakat untuk memperoleh akses informasi yang benar, jujur, dan tidak diskriminatif tentang penyelenggaraan organisasi dengan memperhatikan perlindungan hak atas pribadi, golongan dan rahasia negara." (Edah Jubaedah, 2008: 20)

Transparansi adalah suatu keterbukaan secara sungguh-sungguh, menyeluruh dan memberi tempat bagi parsitifasi aktif dari seluruh lapisan masyarakat dalam proses pengelolaan sumber daya publik." (Nico Ardianto, 2007: 20) Lebih lanjut Sutedi mendefinisikan, "Transparansi adalah prinsip yang menjamin akses atau kebebasan bagi setiap orang untuk memperoleh informasi tentang penyelenggaraan pemerintah, yakni informasi tentang kebijakan, proses pembuatan dan pelaksanaannya, serta hasil-hasil yang dicapai. (Adrian Sutedi, 2009: 20)

Transparansi adalah memberikan keterbukaan informasi yang menyeluruh kepada pihak-pihak yang membutuhkan. 


\section{Transparansi dalam Al-quran}

1. Shiddiq, benar, nilai dasarnya adalah integritas. Nilai-nilai dalam bisnisnya berupa kejujuran, iklas, terjamin, keseimbangan emosional.

2. Amanah, nilai dasarnya terpercaya dan nilai-nilai dalam bisnisnya ialah adanya kepercayaan, tanggungjawab, transparan dan tepat waktu.

3. Fathanah, nilai dasarnya adalah memiliki ilmu pengetahuan yang luas, nilainilai dalam bisnisnya ialah memiliki visi, pemimpin yang cerdas.

4. Tabligh, nilai dasarnya adalah komunikatif dan nilai bisnisnya ialah supel, penjual yang cerdas, deskripsi tugas,delegasi wewenang, kerja tim, koordinasi, ada kendali dan supervisi. (Muhammad syafi'i Antonio, 2002: 196)

Nilai transparansi sangat menuntut nilai-nilai kejujuran atas setiap informasi dalam sebuah lembaga perusahaan. Sehubungan dengan kejujuran, dalam Al-quran surat Al-Is'ra ayat 35 yaitu:

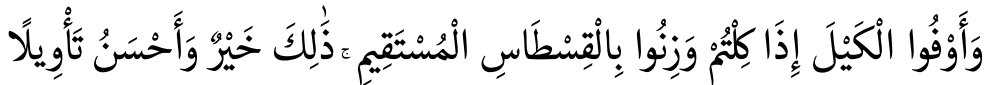

"Dan sempurnakanlah takaran apabila kamu menakar, dan timbanglah dengan neraca yang benar. Itulah yang lebih utama (bagimu) dan lebih baik akibatnya."

Allah berfirman hendaklah kamu sempurnakan takaran apabila kamu menakar dan janganlah sekali-kali kamu berlaku curang dalam takaranmu untuk menambah keuntungan dengan merugikan orang lain, demikian pula kamu harus berlaku jujur dan adil jika menimbang dengan menggunakan neraca yang benar. Sikap dan cara yang demikian itu adalah lebih baik abi kamu di dunia maupun di akhirat. (Salim Bahreisy dan Said Bahreisy, 2004: 42),

Menekankan sikap transparan (keterbukaan/kejujuran) sangat penting untuk diperhatikan karena dalam surat al-Muthaffifin Allah telah mengatakan:

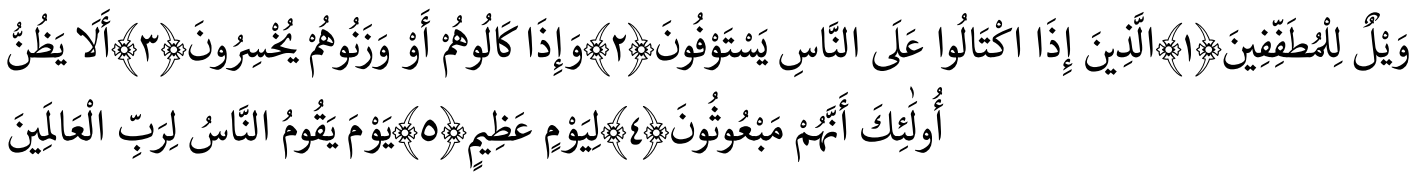

"kecelakaan besarlah bagi orang-orang yang curang (yaitu) orang-orang yang apabila menerima takaran dari orang lain mereka minta dipenuhi, dan apabila mereka menakar atau menimbang untuk orang lain, mereka mengurangi. Yang dimaksud dengan orang-orang yang curang disini ialah orang-orang yang curang dalam menakar dan menimbang."

\section{Tujuan Transparansi}

Adapun tujuan transparansi terhadap pengelolaan keuangan yang dapat dirasakan oleh skakeholders dan lembaga adalah: 
1. Mencegah sedini mungkin terjadinya penyimpangan-penyimpangan melalui kesadaran masyarakat dengan adanya kontrol sosial.

2. Menghindari kesalahan komunikasi dan perbedaan persepsi.

3. Mendorong masyarakat untuk belajar bertanggung jawab dan bertanggung gugat terhadap pilihan keputusan dan pelaksanaan kegiatan.

4. Membangun kepercayaan semua pihak dari kegiatan yang dilaksanakan.

Tercapainya pelaksanaan kegiatan sesuai dengan ketentuan, prinsip dan nilainilai universal. (Transparansi Akuntabilitas, 2005: 8) Dalam modul Komunitas mengenai transparansi dan akuntabilitas, dijelaskan bahwa penerapan transparansi dan akuntabilitas bertujuan agar masyarakat belajar dan melambangkan sikap bertanggung jawab serta tanggung gugat terhadap pilihan keputusan dan kegiatan yang dilaksanakan. (Werren Bennis, dkk, 2009: 103)

Warren Bennis mengemukakan bahwa tujuan transparansi, yaitu menciptakan keterbukaan kepada masyarakat dalam setiap program atau kegiatan yang dilaksanakan, mengakses informasi, meningkatkan kepercayaan dan kerja sama antara pengelola dan pemangku kepentingan. (Simon Werinom, dkk, 2007: 8)

Mardismo dalam Simson Werinom mengemukakan, bahwa tujuan transparansi dalam menyusun anggaran terdapat 5 kriteria, adalah:

1. Tersedianya pengumuman kebijakan anggaran.

2. Tersedianya dokumen anggaran dan mudah di akses.

3. Tersedianya laporan pertanggungjawaban yang tepat waktu.

4. Terakomodasinya usulan/suara rakyat

5. Tersedianya sistem pemberian informasi kepada publik. (Sri Minarti, Opcit: 24)

Dari uraian di atas, maka dapat disimpulkan bahwa tujuan transparansi dapat menimalisirpenyimpangan-penyimpangan penggunaan dana, mencegah ketidakpercayaan publik dan tercapainya tujuan.

\section{Manfaat Transparansi}

Manfaat dari adanya transparansi dapat menciptakan kepercayaan timbal balik antar pemerintah, masyarakat dan karyawan memlalui penyediaan informasi dan menjamin kemudahan di dalam memperoleh informasi yang akurat dan memadai." (Nico Andrianto, 2007: 21)

Beberapa manfaat penting adanya transparansi anggaran adalah sebagai berikut: 
1. Mencegah korupsi.

2. Lebih mudah mengindefikasi kelemahan dan kekuatan kebijakan.

3. Meningkatkan akuntabilitas sehingga masyarakat akan lebih mampu mengukur kinerja lembaga.

4. Meningkatkan kepercayaan terhadap komitmen lembaga untuk memutuskan kebijakan tertentu.

5. Menguatnya kohesi sosial, karena kepercayaan masyarakat terhadap lembaga.

6. Menciptakan iklim investasi yang baik dan meingkatkan kepastian usaha. (T.Hani Handoko,1994: 155)

\section{A. Bagi Hasil \\ 1. Pengertian Bagi Hasil}

Istilah bagi hasil sebenarnya bukan hal baru dalam kegiatan ekonomi di indonesia. Sistem bagi hasil sudah di kenal sejak dahulu melalui bagi hasil pertanian yang dilakukan oleh penggarap dan pemilik lahan.

Prinsip bagi hasil adalah prinsip yang digunakan untuk usaha kerja sama yang ditujukan guna mendapatkan barang dan jasa sekaligus. Keuntungan ditentukan oleh nisbah bagi hasil yang disepakati dimuka dan tingkat keuntungan ditentukan dari besarnya keuntungan usaha sesuai dengan prinsip bagi hasil. Prinsip bagi hasil ini dapat dilakukan dengan menggunakan akad musyarakah dan mudharabah.

2. Musyarakah

Jenis-jenis Musyarakah

a. Syirkah Al-Inan

Syirkah Al-Inan adalah kontrak antara dua orang atau lebih. Setiap pihakmemberikan suatu porsi dari keseluruhan dana dan berpartisipasi dalam kerja.kedua pihak berbagi dalam keuntungan dan kerugian sebagaiman yang disepakati diantara mereka. Akan tetapi, porsi masing-masing pihak, baik dalam dana maupun kerja atau bagi hasil, tidak harus sama dan identik sesuai dengan kesepakatan mereka. Manyoritas ulama membolehkan jenis al-musyarakah ini.

\section{b. Syirkah Mufawadah}

Syirkah mufawadah adalah kontrak kerja sama antara dua orang atau lebih. Setiap pihak memberika suatu porsi dari keseluruhan dana dan berpartisipasi dalam kerja. Setiap pihak membagi keuntungan dan kerugian secara sama. Dengan demikian, syarat utama dari jenis al-musyarakah mufawadhah adalah 
kesamaan dana yang diberikan, kerja, tanggungjawab dan beban utang dibagi oleh masing-masing.

c. Syirkah A'maal

Al-musyarakah a'maal adalah kontrak kerja sama dua orang seprofesi untuk menerima pekerjaan secara bersama dan berbagi keuntungan dari pekerjaan itu. Misalnya, kerjasama dua orang arsitek untuk menggarap sebuah proyek, atau kerjasama dua orang penjahit untuk meneriam order pembuatan seragam. Al-musyarakah ini kadang-kadang disebut musyarakah abdan atau sana'i.

d. Syirkah Wujuh

Syirkah wujuh adalah kontrak antara dua orang atau lebih yang memiliki reputasi dan prestise baik serta ahli dalam bisnis. Mereka membeli barang secara kredit dari suatu perusahaan dan menjual barangtersebut secara tunai. Mereka berbagi dalam keuntungan dan kerugian berdasarkan jaminan kepada penyuplai yang disediakan oleh tiap mitra. Jenis musyarajag ini tidak memerlukan modal karena pembelian secra kredit berdasar pada jaminan tersebut. Karenanya, kontrak ini pun lazim disebut sebagai musyarakah piutang.

3. Mudharabah

Jenis-jenis Al-mudharabah

1. Mudharabah Muthlaqah

Yang dimaksud dengan transaksi mudharabah muthlaqah adalah bentuk kerjasama antara shahibul maal dan mudharib yang cakupannya sangat luas dan tidak dibatasi oleh spesifikasi jenis usaha, waktu, dan daerah bisnis. Dalam pembahasan fiqh ulama salafus saleh sering kali dicontohkan dengan ungkapan if'al ma syi'ta ( lakukanlah sesukamu) dari shahibul maal ke mudharib yang memberi kekuasaan sangat besar.

\section{Mudharabah Muqayyadah}

Mudharabah muqayyadah atau disebut juga dengan istilah restricted mudharabah/specified mudharabah adalah kebalikan dari mudharabah muthlaqah. Si mudharib dibatasi denga batasan jenis usaha, waktu, atau tempat usaha. Adanya pembatasan ini seringkali mencerminkan kecendrungan umum si shahibul maal.

\section{METODOLOGI}

Pendekatan penelitian ini adalah pendekatan penelitian kualitatif yaitu suatu prosedur penelitian yang menghasilkan data deskriptif berupa ucapan atau tulisan dan perilaku yang dapat diamati dari orang-orang (subyek) itu sendiri. (Sadili Samsudin, 2006:188) 
Mahlel, Ridwan, Nasirwan: Akuntabilitas dan Transparansi

Pendekatan penelitian kualitatif, merupakan semua fakta berupa kata-kata lisan maupun tulisan dari sumber data manusia yang telah diamati dan dokumen terkait lainnya disajikan dan digambarkan apa adanya untuk selanjutnya ditelaah guna menemukan makna. Metode kualitatif digunakan karena beberapa pertimbangan yaitu metode kualitatif lebih bisa dan mudah menyesuaikan apabila berhadapan dengan kenyataan ganda, metode ini menyajikan hakekat hubungan antara peneliti dan responden secara langsung dan metode ini lebih peka sehingga dapat menyesuaikan diri dan banyak penajaman pengaruh bersama terhadap pola-pola nilai yang dihadapi peneliti. (Arif Furchan, 1992: 21)

\section{HASIL DAN PEMBAHASAN}

Pencatatan dalam laporan keuangan dilakukan oleh pengelola dimana laporan keuangan tersebut sangat dibutuhkan oleh pemodal dan karyawan. Pengelola juga mempunyai tugas dan tanggungjawab, sebagai berikut:

a. Menerima dan memproses faktur dari pemasok.

b. Memproses seluruh transaksi penjualan dan pembelian perusahaan.

c. Melakukan penagihan piutang dagang kepada pelanggan.

d. Membuat laporan keuangan secara berskala.

e. Membuat catatan setiap mata barang yang laku terjual.

Dengan membuat semua catatan laporan uang yang masuk dan uang yang keluar dan barang yang masuk dan barang yang keluar merupakan dasar dari transparansi. Semua karyawan berhak mengetahui informasi keadaan barang dan informasi keuangan. Hal ini untuk menumbuhkan sikap saling percaya antara sesama karyawan.

Sistem bagi hasil merupakan salah satu sistem pemberian kompensasi di Kota Beureunuen. Kompensasi bagi hasil dibagikan kepada karyawan setelah sampai kiraan dalam jangka waktu setahun. Tidak di ketahui persis sejak kapan cara bagi hasil dengan karyawan ini dilakukan oleh para pengusaha-pengusaha toko di Kota Beureunuen.

Karyawan yang di berikan hak kompensasi bagi hasil bagi karyawan yang sudah mampu melayani konsumen dan menguasi sebagian nama mata barang. Untuk karyawan yang baru mereka dianggap magang atau belajar dalam jangka waktu kiraan setahun, setelahnya maka karyawan tersebut akan mendapatkan kompensasi bagi hasil. Bagi karyawan yang baru magang atau belajar mereka hanya akan mendapatkan bonus. (Ahmad Tanzeh dan Suyitno, 2006: 116)

Karyawan yang di berikan hak bagi hasil tidaklah sama, mereka diberikan sesuai dengan kemampuan dan tanggung jawab. Kemampuan dan tanggung jawab lebih besar bagi karyawan yang sudah lama atau senior dalam hal ini senior harus mampu men- 
guasai keadaan di toko. Pembagian bagi hasil dilakukan dengan sistem 50:50, dari hasil perolehan laba dalam satu tahun hijriah. 50 persen diberikan untuk hak modal dan 50 persen untuk hak kerja. 50 persen hak karyawan tidaklah dibagi rata, karena mereka diberikan bagi hasil sesuai dengan kemampuan dan tanggung jawab. Didalam 50 persen hak karyawan, pemodal juga memiliki hak karena pemodal dianggap berkerja, tugas pemodal adalah mengontrol, penasehat dan penanggung jawab tertinggi, maka pemodal mendapatkan 10 persen dari hak kerjanya.

Dalam sistem bagi hasil, tidak ada atasan dan bawahan yang beda hanyalah dalam hal kemampuan dan tanggung jawab, maka karyawan yang senior dan yang sudah lama memiliki lebih kemampuan dan tanggung jawab daripada karyawan yang baru junior. Suasana di toko lebih akrab dan bersifat kekeluargaan sesama karyawan dan pemodal, karyawan dalam berkerja atas kesadaran masing-masing dan sama-sama menjaga tanggung jawab dan kewajiban.

Sistem bagi hasil dianggap lebih baik karena semakin banyak pendapatan laba perusahaan, maka semakin banyak hak karyawan, dengan sistem bagi hasil membuat karyawan semakin giat, tidak bermalas-malasan dan terus berusaha walaupun tidak ada target yang di tetapkan oleh perusahaan. Dengan cara ini karyawan lebih sejahtera di bandingkan dengan karyawan yang di gaji atau di berikan upah harian atau bulanan. Kerena gaji atau upah harian dan bulanan sudah ada patokan masing-masing, sedangkan bagi hasil tidak adanya patokan kompensasi. Maka Perolehan laba perusahaan dapat di nikmati secara bersama-sama antara pemodal dan karyawan, maka sistem bagi hasil lebih mensejahterakan karyawan.

Kejujuran karyawan dalam sistem bagi hasil lebih terjamin, karena hak para karyawan penuh diberikan. Jika karyawan membutuhkan uang, maka bisa meminjamkan pada pengelola keuangan. Setiap pinjaman akan di catat dan akan dikurangi pendapatan kompensasi karyawan pada masa kiraan. Begitu juga dengan pemodal harus menulis pinjaman di buku catatan harian. Dan apabila membutuhkan uang dalam jumlah tertentu maka pemodal atau karyawan harus memberi tau bagian keuangan beberapa hari sebelum di butuhkan.

Perhitungan perolehan laba bagi hasil antara pemodal dan karyawan dilakukan dalam satu tahun hijriah. Hal ini dilakukan dikarenakan untuk mengetahui jumlah zakat tijarah yang akan dikeluarkan dalam setiap satu tahun Hijriah. Untuk mengetahui berapa laba dalam penjualan satu tahun, maka hal yang pertama dilakukan adalah menghitung seluruh barang dalam toko dan gudang-gudang. Setelah mengetahui jumlah barang maka di dihargakan masing-masing mata barang dengan harga beli di tambah dengan ongkos kirim, tambahkan dengan uang kas tunai dan uang sewa toko untuk 
Mahlel, Ridwan, Nasirwan: Akuntabilitas dan Transparansi

tahun selanjutnya yang telah lebih dulu dikeluarkan. Dan di tambah pula dengan uang ambilan kontan dalam satu tahun tersebut.

Setelah mengetahui jumlah uang dari penambahan jumlah barang dan kas, maka dari jumlah tersebut di kurangi 2,5 persen untuk zakat tijarah dalam satu tahun. Total dari penjumlahan barang dan kas tunai maka di kurangi zakat dari 2,5 persen. Jumlah total setelah dikurangi zakat, maka di kurangilah dengan hutang-hutang pihak lain. Selanjutnya di tambah dengan piutang, dari semua jumlah piutang nantinya akan di potong persen, jumlah yang di potong di musyawarahkan untuk kesepakatan antara pemodal dan karyawan. Hal ini dilakukan karena semua piutang tidak akan terbayar lunas.

Setelah menambah piutang maka barulah diketahui jumlah keseluruhan dan dari jumlah besar, Maka di kurangilah dengan modal tahun yang lalu. Setelah di kurangi modal tahun yang lalu maka di kurangi 10 persen untuk piutang, ${ }^{2}$ barang-barang rusak dan barang-barang yang sudah kadaluarsa, maka diketahuilah laba bersih dalam satu tahun. Yang membuat pemilik melakukan sistem bagi hasil dengan karyawan adalah:

a. Adanya rasa sama-sama memiliki perusahaan antara pemodal dengan karyawan.

b. Karyawan menjaga perusahaan seperti miliknya sendiri.

c. Perolehan laba di akhir tahun sama-sama merasakann

d. Pemodal dan karyawan saling bertanggung jawab terhadap perusahaan.

e. Karyawan tidak melepaskan tanggung jawab yang telah diberikan.

f. Menumbuhkan rasa dan sikap kekeluargan antar sesama karyawan dan pemodal.

Hal yang membuat karyawan berkerja dengan bagi hasil:

a. Lebih menguntungkan sistem bagi hasil daripada dengan sistem gaji harian atau bulanan.

b. Bagi hasil menjaminkan kesejeteraan karyawan.

c. Merasa nyaman dalam berkerja karena sifat kekeluargaan.

\section{Akuntabilitas}

Setiap transaksi pembelian maupun penjualan dan pencatatan barang yang masuk maupun barang yang keluar, pengolala diwajibkan oleh pimpinan untuk mencatat transaksi tersebut, untuk lebih mudah dalam pertanggungjawaban keuangan perusahaan. Akuntabilitas dan amanah tidak dapat dipisahkan. Akuntabilitas yang baik baik, di awali oleh transparansi pemodal. Akuntabilitas laporan merupakan bentuk pertanggungjawaban secara tertulis, baik dalam pelaporan program kerja maupun pelaporan keuangan yang di buat oleh pengelola (karyawan) toko untuk memudahkan pemodal melihat keuangan perusahaan dan karyawan. 
Dalam hal pembuat laporan akuntabilitas pengelola harus memiliki sifat amanah. Amanah adalah menyampaikan hak apa saja kepada pemiliknya, tidak mengambil sesuatu melebihi haknya dan tidak mengurangi hak orang lain. Dengan kata lain, Amanah merupakan hak bagi mukallaf yang berkaitan dengan hak orang lain untuk menunaikannya karena menyampaikanamanah kepada orang yang berhak memilikinya adalah suatu kewajiban. Pada prinsipnya, amanah merupakan bentuk pertanggungjawaban kepada Allah Swt sebagai Sang Pemberi amanah untuk menggunakan dengan cara dan tujuan yang ditetapkan. Dalam pengelolaan keuangan perusahaan, amanah merupakan bentuk pertanggungjawaban kepada pengelola dan karyawan, sesuai dengan syari'ah Islam yaitu Al-Qur'an dan Al-Hadist.

Pertanggungjawaban kepada Tuhan berkaitan dengan sifat amanah. Amanah merupakan perilaku yang wajib dimiliki oleh insan kehidupan. Perilaku ini juga merupakan pengajaran tertinggi didalam Islam. Amanah dalam konteks praktek akuntansi, diinterpretasikan sebagai akuntabilitas, dalam pengertian bahwa orang-orang yang memegang amanah harus bertanggung jawab kepada pemegang saham, pelaksana, karyawan dan Tuhan.

Nilai amanah akan memberikan motivasi kepada karyawan untuk menjalankan dengan sebaik-baiknya sesuai dengan Al-Qur'an dan Al-Hadist karena mereka merasa yakin bahwa segala sesuatu akan dipertanggungjawabkan kepada Allah SWT. Nilai amanah bagi karyawan akan dapat menumbuhkan kesadaran bahwa semua pengeluaran perusahaan bisa di pertanggung jawabkan oleh pengelola toko, sehingga menumbuhkan rasa bertambah giat dalam berkerja, meningkatkan kesenangan dan keikhlasan.

Dalam Al-Qur'an, dalam surah An-Nisa ayat 58 Allah SWT berfirman:



"Sesungguhnya Allah menyuruh kamu menyampaikan amanat kepada yang berhak menerimanya, dan (menyuruh kamu) apabila menetapkan hukum di antara manusia supaya kamu menetapkan dengan adil. Sesungguhnya Allah memberi pengajaran yang sebaik-baiknya kepadamu. Sesungguhnya Allah adalah Maha mendengar lagi Maha melihat".(An-Nisa: 58)

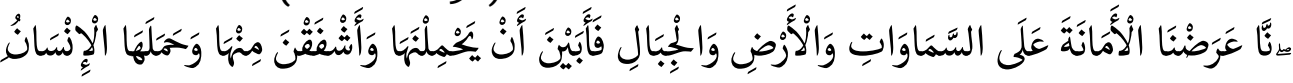

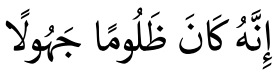

Sesungguhnya Kami telah mengemukakan amanat kepada langit, bumi dan gununggunung, Maka semuanya enggan untuk memikul amanat itu dan mereka khawatir akan mengkhianatinya, dan dipikullah amanat itu oleh manusia. Sesungguhnya 
manusia itu Amat zalim dan Amat bodoh. (Al-Ahzab: 72)

Akuntabilitas juga mewujudkan nilai transparan yang bersifat amanah dan profesional. Pembentukan laporan yang bersifat transparan merupakan amanah Allah SWT yang tertuang dalam Al-Qur'an Surah Al-Baqarah ayat 282, sehingga prinsip ini harus benar-benar dilaksanakan oleh pengelola perusahaan untuk mewujudkan akuntabilitas laporan. Laporan yang bersifat transparan juga akan meningkatkan kepercayaan pemodal dan karyawan secara profesional.

\section{Transparansi}

Prinsip Transparansi sangat di butuhkan dan harus di laksanakan oleh pemodal dan karyawan, agar tidak terjadi kesalahpahaman antara pemodal dan karyawan. Dalam mewujudkan transparansi sebuah perusahaan harus menyediakan informasi yang cukup, akurat dan tepat waktu, baik pemodal kepada karyawan maupun karyawan kepada pemodal. Dalam laporan keuangan yang wajib di ungkapkan secara objektif dan mudah dimengerti.

Salah satu cara untuk melaksanakan sistem bagi hasil antara pemodal dan karyawan adalah dengan adanya transparansi keterbukaan informasi. Keterbukaan informasi adalah adanya akses untuk karyawan, untuk mengetahui tentang modal, perolehan laba perusahaan dalam satu tahun hijriah. Transparansi adalah sesuatu yang dipercayakan kepada seseorang, baik harta, ilmu pengetahuan, dan hal-hal yang bersifat rahasia yang wajib dipelihara atau disampaikan kepada yang berhak menerima, harus disampaikan apa adanya tidak boleh dikurangi maupun ditambah. Orang yang jujur adalah orang yang mengatakan sebenarnya, walaupun terasa pahit untuk disampaikan.

Dengan adanya penerapan akuntabilitas pada perusahaan maka setiap karyawan bisa melihat informasi tentang keadaan perusahaan tersebut, setiap karyawan berhak untuk mengetahui informasi tentang perusahaan, apabila puas dengan informasi maka karyawan akan lebih termotivasi untuk terus berkerja. Sesungguhnya orang yang paling baik untuk kita ambil sebagai pekerja adalah orang yang memiliki kemampuan dan terpercaya (Alquran 28: 26).Sifat jujur atau dapat dipercaya merupakan sifat terpuji yang disenangi Allah, walaupun disadari sulit menemukan orang yang dapat dipercaya.Kejujuran adalah sesuatu yang mahal. Lawan dari kejujuran adalah penipuan.

Janganlah kamu memperhatikan banyaknya salat dan puasanya. Jangan pula kamu perhatikan banyaknya haji dan kesalehannya. Tetapi perhatikanlah kejujurannya dalam menyampaikan informasi dan menjalankan amanat (Nabi Muhammad saw, Bihar 
al-Anwar 75: 114). Kejujuran akan menyelamatkan kamu walaupun kamu takut padanya; dan kebohongan mencelakakan kamu walaupun kamu tenteram karenanya (Ali bin Abi Thalib, Ghurar al-Hikam).

Dalam dunia bisnis pada umumnya kadang sulit sekali untuk mendapatkan kejujuran. Oleh karena itu kejujuran sangat penting dalam melakukan berbagai kegiatan dalam kehidupan untuk memperoleh hasil yang maksimal. Prinsip transparansi tidak hanya untuk melindungi pemegang saham minoritas akan tetapi juga bagaimana perusahaan dioperasikan dan bisnis dijalankan sehingga dapat berinteraksi dengan masyarakat luas.

Transparansi akan terlaksana dengan baik, apabila pemodal dan karyawan beriman dan bertaqwa kepada Allah SWT. Dengan beriman dan bertaqwa, pemodal maupun karyawan akan saling menjaga hak dan kewajibannya dan tanggung jawab masing-masing. Dengan transparannya pemodal maka hak dari jerih payah kerja karyawan akan diberikan semua hak karyawan oleh pemodal. Begitu juga dengan dengan karyawan, apabila hak dari jerih payahnya diberikan maka, karyawan akan menjaga hak dan kewajiban dan karyawan akan jujur dan lebih transparan.

Dalam Al-qur'an surat Surat Al-Qasas ayat 26,



"salah seorang dari kedua wanita itu berkata: "Ya bapakku ambillah ia sebagai orang yang bekerja (pada kita), karena Sesungguhnya orang yang paling baik yang kamu ambil untuk bekerja (pada kita) ialah orang yang kuat lagi dapat dipercaya."

Janganlah kamu memperhatikan banyaknya salat dan puasanya. Jangan pula kamu perhatikan banyaknya haji dan kesalehannya. Tetapi perhatikanlah kejujurannya dalam menyampaikan informasi dan menjalankan amanat (Nabi Muhammad saw, Bihar al-Anwar 75: 114). Kompentensi utama karyawan yaitu kejujuran dan Transparansi, "Abu Humaid meriwayatkan bahwa Nabi SAW mengangkat seorang laki-laki dari suku Azd menjadi amil Zakat. la disebut orang Ibnu al-lutbiah. Satu waktu ia datang menhadap Nabi, lalu berkata, “ini bagian untukmu, dan ini hadah untuk saya.

Kemudian Rasullullah SAW. Berdiri dan mengucapkan puji kepada Allah dan selanjutnya beliau bersabda, "aku telah menggangkat dari kalanganmu orang ini untuk untuk mengerjakan sesuatu yang diserahkan Allah kepadaku. Lalu suatu ketika ia datang dan berkata, "ini untukmu, dan ini hadiah untukku”. Bila ia jujur maka, seandainya ia diam dirumah orang tuanya, hadiah itu akan datang kepadanya. Demi Allah, jika seseorang daripadamu mengambil sesuatu yang bukan haknya, maka ia akan membawa barang itu di hari kiamat pada waktu ia menghadap Allah. Saya tidak tahu apakah di 
Mahlel, Ridwan, Nasirwan: Akuntabilitas dan Transparansi

antara kamu di hari kiamat nanti ada yang membawa unta sedang menguak, sapi sedang melenguk atau kambing yang mengambik.

\section{SIMPULAN}

Berdasarkan hasil penelitian yang telah peneliti uraikan maka simpulan yang diperoleh adalah: Pertama, Bahwa toko yang menerapkan sistem bagi hasil dengan karyawan memiliki laporan keuangan yang sangat transparansi dan catatan yang sangat akuntabilitas. Pemilik modal membari tahu kepada semua karyawan modal pada tahun tersebut. Dalam hal pengelolaan pemilik modal tidak melakukan interverensi terhadap para karyawan selain menerapkan kedisiplinan yang tinggi. Prinsip transparansi dan akuntabilitas membuat karyawan lebih positif dalam berkerja. Pemilik modal tidak merisaukan dengan moral hazard dengan sistem bagi hasil karena hak kerja karyawan di berikan sepenuhnya. Begitu juga karyawan tidak melakukan hal-hal yang bertentangan dengan agama karena mereka mempunyai pendapatan masing-masing yang cukup. Kedua, Kesesuaian praktik bagi hasil dengan karyawan di kota Beureunuen dengan sistem bagi hasil dalam fiqh muamalah di kategorikan dalam akad mudharabah, karena yang pemilik modal hanya satu orang. Dalam penentuan perhitungan nisbah bagi hasil dengan model revenue sharing. Dan upah atau gaji harian tidak di masukkan dalam pendapatan sistem bagi hasil.

\section{PUSTAKA ACUAN}

Azhari Akmal Tarigan 2012.Tafsir Ayat-Ayat Ekonomi. Bandung: Citapustaka Media Perintis

H. Burhanuddin Yusuf. 2006.Manajemen sumberdaya manusia di lembaga keuangan Syariah. Jakarta: PT RajaGrafindo Persada

Isnaini, dkk. 2015. Hadis-Hadis Ekonomi. Jakarta: Prenadanadia Group

M. Quraish Shihab. 2003. Tafsir Al-Mishbah, vol 10. Jakarta: Lentera Hati

Mardiasmo. 2002.Otonomi dan Manajemen Keuangan Daerah. Yogjakarta: Andi

Rosjidi. 2001Akuntansi Sektor Publik: Kerangka Standart Dan Metode. Surabaya : Aksara Satu

Sadili Samsudin. 2006. Manajemen Sumber Daya Manusia. Bandung: Pustaka Setia

Sony Yuwono. 2005. Penganggaran Sektor Publik: Pedoman Praktis Penyusunan, Pelaksanaan dan Pertanggungjawaban APBD (Berbasis Kinerja). Malang: Bayumedia Publishing

Syahruddin Rasul 2002. Pengintegrasian Sistem Akuntabilitas Kinerja dan Anggaran,Jakarta: Detail rekod 
T. Hani Handoko. 1994.Manajemen Personalia Dan Sumber Daya Manusia, (Yogjakarta: BPFE Yogjakarta

Veithzal Rivai dan Ella J. Sagala. 2009.Manajemen Sumber Daya Manusia. Jakarta: Rajawali Pers 